Coleman, G. S. (1956). J. gen. Microbiol. 15, 248-256

\title{
The Dissimilation of Amino Acids by Rhodospirillum rubrum
}

\author{
By G. S. COLEMAN \\ Department of Biochemistry, University of Cambridge
}

SUMMARY: Washed suspensions of a strain of Rhodospirillum rubrum $\mathrm{S} 1$ grown anaerobically in the light and incubated in the light under argon metabolized many of the $\mathbf{1 5}$ amino acids tested and produced ammonia and carbon dioxide as the principal extracellular products. Hydrogen was also produced in the presence of glutamic acid. Of the glutamic acid metabolized $80 \%$ of the carbon and $55-70 \%$ of the nitrogen were converted into intracellular products. The magnitude of the catabolism of the other amino acids, as measured by ammonia and carbon dioxide production, appears to be an inverse function of the closeness to which the elemental composition of the amino acid approximates to that of cell material.

When the organism was grown aerobically in the dark, studies of the metabolism of amino acids by washed suspensions, under aerobic conditions, were complicated by the relatively high rate of endogenous respiration. In the presence of certain amino acids this was decreased by $9 \%$ (with alanine) to $45 \%$ (with aspartic acid), and glutamic acid, aspartic acid and alanine, at least, were oxidized to completion by the organism.

Although Rhodospirillum rubrum can utilize amino acids as sole hydrogen donor and nitrogen source for growth, no systematic studies on its amino acid metabolism have been published as far as the author is aware. The work described in this paper is the first part of an attempt to elucidate the mechanism of amino acid metabolism by washed suspensions of the organism when grown under anaerobic conditions in the light or under aerobic conditions in the dark. Hereafter suspensions grown under these two conditions will be referred to as 'light-grown organisms' and 'dark-grown organisms' respectively.

\section{METHODS}

Organism. The organism used in the studies with dark-grown organisms was Rhodospirillum rubrum, strain S 1, kindly supplied by Dr S. R. Elsden. For the experiments with light-grown organisms a mutant strain which arose spontaneously was used. This differed from the parent in that it had a high rate of endogenous gas production and produced hydrogen in the presence of glutamic acid. It was maintained by weekly transfers in stab culture on $2 \%(\mathrm{w} / \mathrm{v})$ agar plus $0.3 \%(\mathrm{w} / \mathrm{v})$ Difco Yeast Extract, growth occurring in the light.

Growth conditions. The medium used throughout this work was based on that described by Kohlmiller \& Gest (1951), and contained per litre: DL-malic acid, $6 \mathrm{~g}$.; L-glutamic acid, $2 \mathrm{~g}$.; $\mathrm{FeSO}_{4} .7 \mathrm{H}_{2} \mathrm{O}, 5 \mathrm{mg}$.; biotin, $10 \mu \mathrm{g}$.; Difco Yeast Extract, $600 \mathrm{mg}$; trace element solution, $1.0 \mathrm{ml}$; mineral salts solution

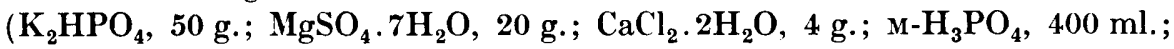
per litre of solution), $10 \mathrm{ml}$.; the $\mathrm{pH}$ value was adjusted to 6.7 with $\mathrm{NaOH}$ before 
autoclaving. Inoculations of the growth vessels were with $0 \cdot 1 \%(\mathrm{v} / \mathrm{v})$ of a culture which had been grown in the light in $5 \mathrm{ml}$. of the above medium in a cotton-plugged test tube for $48 \mathrm{hr}$.

Light-grown organisms were cultured in a completely full reagent bottle and grown for $3 \frac{1}{2}$ days at $30^{\circ}$ in an incubator illuminated by three $40 \mathrm{~W}$. tungsten filament lamps at a distance of $25 \mathrm{~cm}$. The organisms were harvested at a density of about $0.8 \mathrm{mg}$. dry wt./ml. Dark-grown organisms were grown for $3 \frac{1}{2}$ days in the dark at $30^{\circ}$ in Roux bottles containing $150 \mathrm{ml}$. of medium.

Washed suspensions were prepared by harvesting and washing twice with $0 \cdot 067 \mathrm{M}$-phosphate buffer $\left(\mathrm{pH} \mathrm{7 \cdot 0)}\right.$ containing $0.03 \% \mathrm{Na}_{2} \mathrm{~S} .9 \mathrm{H}_{2} \mathrm{O}$. The cells were finally suspended in this buffer at a density of $10-40 \mathrm{mg}$. dry wt./ml. Dry weights were determined by drying a sample to constant weight at $105^{\circ}$ and applying a correction for the weight of salt present in the suspending medium.

Manometric techniques. Most of the experiments described were carried out in double side bulb Warburg manometers at $30^{\circ}$. In each experiment $1.0 \mathrm{ml}$. of the suspension was placed in the main compartment of the vessel, together with $1.0 \mathrm{ml}$. of $0.1 \mathrm{M}$-phosphate buffer and $0.5 \mathrm{ml}$. of substrate added from a side bulb after a 10-15 min. period of equilibration in the dark. To obtain consistent results in experiments with light-grown organisms it was necessary to avoid delay in dispensing the suspension, and in gassing and equilibrating the manometers. For the experiments performed in the light, the manometers were illuminated from below by a bank of eight $60 \mathrm{~W}$. lamps which were turned on immediately after the addition of the substrate. In the dark experiments each vessel was covered with a small black bag. The reactions were terminated by the addition of $0.5 \mathrm{ml} . \mathrm{N}-\mathrm{H}_{2} \mathrm{SO}_{4}$ except in experiments involving total nitrogen determinations on the supernatant fluids and those to determine intracellular products of glutamic acid dissimilation.

In manometric experiments, where the gas phase was argon and a $\mathrm{KOH}$ paper was present, any gas evolved was taken to be hydrogen. Proof that this was so depends on the fact that it was absorbed by palladized asbestos plus methylene blue (Gest, Kamen \& Bregoff, 1950) and that little or no gas was produced in the presence of both hydrogen and carbon dioxide absorbers. Thus hydrogen and carbon dioxide were apparently the only gases produced during metabolic experiments.

In the absence of a KOH paper both hydrogen and carbon dioxide were evolved. The amounts of the two gases were measured in the following manner. The reaction was carried out in a Warburg manometer with two side arms, one of which contained the substrate and the other $0.5 \mathrm{ml} . \mathrm{N}_{-}-\mathrm{H}_{2} \mathrm{SO}_{4}$ and also a sealed bulb containing $0.03 \mathrm{ml} .20 \% \mathrm{NaOH}$. This bulb could be crushed by rotating the stopper, the end of which had been lengthened to extend into the side bulb. When the experiment was completed, the acid was tipped in from the side arm to release any combined carbon dioxide, and the total pressure change due to hydrogen plus carbon dioxide measured. The bulb containing the $\mathrm{NaOH}$ was then crushed and the carbon dioxide absorbed. The change in pressure was measured, and from the two readings the volumes of hydrogen 
and carbon dioxide evolved during the reaction were calculated. Correction for the carbon dioxide initially present was made by running a parallel manometer in which the acid was tipped and the bulb containing $\mathrm{NaOH}$ crushed immediately after equilibration.

Respiratory quotients (R.Q.) were measured by the three vessel technique described by Umbreit, Burris \& Stauffer (1949). Good agreement for ammonia production and amino acid disappearance was found between the vessels with and without $\mathrm{KOH}$ paper, showing that the amino acid metabolism was not seriously affected by removal of carbon dioxide.

At the end of the experiment the contents of each manometer vessel were washed out, made up to $10 \mathrm{ml}$. with water and the bacterial cells centrifuged off. Samples of the supernatant fluids were then used for total nitrogen, ammonia and amino acid determinations.

Analytical methods. Total nitrogen in the supernatants was determined by a micro-Kjeldahl method using the catalyst described by Chibnall, Rees \& Williams (1943). The ammonia was estimated spectrophotometrically using Nessler's reagent after distillation in a Markham microdistillation apparatus (Markham, 1942) from a strongly alkaline solution. Free ammonia in suspension fluids was estimated similarly. When glutamine was present the $\mathrm{pH}$ value was adjusted to $\mathbf{9 \cdot 3}$ and the ammonia distilled off by the method of Parnas \& Heller (1924). L-Glutamic acid and L-glutamine were estimated together, using the specific L-glutamic acid decarboxylase of Clostridium welchii SR 12 (Gale, 1945). Other amino acids were estimated by the photometric ninhydrin method of Cocking \& Yemm (1954) after the removal of ammonia by heating $1.0 \mathrm{ml}$. of the solution with $0.2 \mathrm{ml}$. N-NaOH on a boiling water-bath for $20 \mathrm{~min}$. followed by neutralization with $0 \cdot 1 \mathrm{~N}-\mathrm{H}_{2} \mathrm{SO}_{4}$. The ninhydrin method gave values for L-glutamic acid which agreed well with those found by the glutamic decarboxylase method and this has been taken as evidence that, during the course of their metabolism, the organisms produced no compounds interfering with the ninhydrin estimation of amino acids.

Measurement of radioactivity of carbon dioxide respired by ${ }^{14} \mathrm{C}-$ labelled organisms. The method was based on that developed by Plackett (personal communication) using a Conway unit (Conway, 1950). The organisms were allowed to metabolize in the outer compartment of a Conway unit and the carbon dioxide evolved was trapped by $0.2 \mathrm{ml}$. saturated $\mathrm{Ba}(\mathrm{OH})_{2}$ on a polythene disk in the centre compartment. At the end of the experiment the solution on the disk was dried in vacuo, and the ${ }^{14} \mathrm{C}$ estimated, using a thin mica end-window GM tube. A drop of indicator added to the disk ensured that the capacity of the baryta had not been exceeded. As the experiments were performed at $\mathrm{pH} \mathrm{7 \cdot 0}$ it was necessary to liberate dissolved carbon dioxide. To do this a small piece of glass tubing of $2 \mathrm{~mm}$. internal diameter, sealed at one end and containing $0.05 \mathrm{ml} .10 \mathrm{~N}-$ $\mathrm{H}_{2} \mathrm{SO}_{4}$, was attached to the ground glass lid of the Conway unit with sealing wax; at the end of the experiment this tube was dislodged and the acid mixed with the contents of the outer compartment. One hour was then allowed for the absorption of the liberated carbon dioxide by the baryta. The experiments were begun by the addition of $1.0 \mathrm{ml}$. of bacterial suspension to $0.8 \mathrm{ml}$. 
0.1 M-phosphate buffer and $0.5 \mathrm{ml}$. substrate in the outer compartment, which was then sealed. A unit in which the acid was added immediately after the bacterial suspension served as a control for the amount of ${ }^{14} \mathrm{CO}_{2}$ present initially. Each estimation was performed in triplicate.

${ }^{14} \mathrm{CH}_{3} \cdot{ }^{14} \mathrm{COONa}$ was supplied by the Radiochemical Centre, Amersham.

\section{RESULTS}

\section{The metabolism of amino acids by light-grown organisms}

Washed suspensions of Rhodospirillum rubrum, when incubated under argon in light, metabolized many of the amino acids tested (Table 1 ). The rates of disappearance and ammonia production from each amino acid were compared to L-glutamic acid. The short chain and most highly oxidized amino acids were metabolized most rapidly. Hydrogen was not produced during the photometabolism of any of the amino acids with the exception of glutamic acid and of proline, the latter increasing the hydrogen production above that of the endogenous value only when the endogenous production was occurring rapidly.

\section{Table 1. Metabolism of amino acids by light-grown organisms}

Experiments carried out in Warburg flasks under argon in light at $30^{\circ}$ in the absence of KOH paper with bacteria suspended in $0.067 \mathrm{M}$-phosphate buffer $\mathrm{pH} 7 \cdot 0$. The rate of amino acid disappearance was compared in each experiment to that of L-glutamic acid. The results are a summary of those from several experiments.

\begin{tabular}{|c|c|c|c|}
\hline Amino acid & $\begin{array}{c}\text { Hydrogen } \\
\text { production }\end{array}$ & $\begin{array}{l}\text { Relative rate of } \\
\text { amino acid dis- } \\
\text { appearance (L- } \\
\text { glutamic acid } \\
=100)\end{array}$ & $\begin{array}{c}\mu \text { mole } \mathrm{NH}_{3} \text { formed } \\
\text { (less endogenous) } \\
\text { per } \mu \text { mole of amino } \\
\text { acid disappearing }\end{array}$ \\
\hline L-Aspartic acid & - & 126 & $0 \cdot 63$ \\
\hline DL-Serine & - & 123 & $0 \cdot 87$ \\
\hline L-Alanine & - & 110 & 0.65 \\
\hline L-Glutamic acid & + & 100 & $0 \cdot 13-0 \cdot 30$ \\
\hline L-Glutamine & - & 61 & 0.81 \\
\hline Glycine & - & 53 & 0.74 \\
\hline DL-Threonine & - & 49 & 0.60 \\
\hline L-Ornithine & - & 33 & . \\
\hline L-Arginine & - & 18 & . \\
\hline L-Proline & $+^{*}$ & 13 & . \\
\hline L-Valine & - & 13 & - \\
\hline L-Histidine & - & 10 & . \\
\hline L-Lysine & - & $\mathbf{9}$ & . \\
\hline L-Leucine & - & $\mathbf{0}$ & . \\
\hline L-Hydroxyproline & - & $\mathbf{0}$ & . \\
\hline
\end{tabular}

* Shown to increase the hydrogen production above that of the endogenous only when the endogenous production was occurring rapidly.

The production of $\mathrm{H}_{2}, \mathrm{CO}_{2}$ and $\mathrm{NH}_{3}$ from amino acids. Table 2 shows the production of hydrogen, carbon dioxide and ammonia during the metabolism of four of the amino acids. In the absence of a $\mathrm{KOH}$ paper, $15-20 \%$ of the glutamic acid carbon appeared as carbon dioxide and 15-30\% of the nitrogen appeared as ammonia. In the presence of a $\mathrm{KOH}$ paper less than $5 \%$ of the 
nitrogen appeared as ammonia. Total nitrogen determinations showed that, in the absence of a $\mathrm{KOH}$ paper, an additional $12-15 \%$ of the glutamic acid nitrogen was present as nitrogen-containing compounds other than ammonia. Small amounts $(12 \mu$ mole from $280 \mu$ mole $\mathrm{L}$-glutamic acid) of volatile fatty acids have been detected in the supernatant fluids. Experiments with ${ }^{14} \mathrm{C}$ glutamic acid (not reported here) indicated that less than $3 \%$ of the glutamic acid carbon which had disappeared from the medium could be accounted for as non-volatile products in the medium. These findings, taken in conjunction with the manometric results, indicate that $80 \%$ of the carbon and $55-70 \%$ c the nitrogen was assimilated by the organism.

\section{Table 2. The dissimilation of amino acids by light-grown organisms}

Experiments carried out in Warburg flasks under argon in light at $30^{\circ}$. Bacteria suspended in 0.067 $\mathrm{M}$-phosphate buffer pH 7.0 at dry wt. : Expt. A, 30.0 mg.; Expt. B, $23 \cdot 1 \mathrm{mg}$. Duration of experiment $3 \mathrm{hr}$.; $50 \mu$ mole of amino acid added initially.

\begin{tabular}{|c|c|c|c|c|c|}
\hline Amino acid & $\begin{array}{l}\text { KOH paper } \\
\text { present }\end{array}$ & $\begin{array}{c}\mathrm{H}_{2} \text { formed } \\
(\mu \text { mole })\end{array}$ & $\begin{array}{c}\mathrm{CO}_{2} \text { formed } \\
(\mu \text { mole })\end{array}$ & $\begin{array}{c}\mathrm{NH}_{3} \text { formed } \\
(\mu \text { mole })\end{array}$ & $\begin{array}{c}\text { Amino acid } \\
\text { metabolized } \\
(\mu \text { mole })\end{array}$ \\
\hline \multicolumn{6}{|c|}{ Expt. A } \\
\hline None & + & $9 \cdot 3$ & . & $\mathbf{0}$ & - \\
\hline & - & 0 & $7 \cdot 0$ & $0 \cdot 6$ & $\cdot$ \\
\hline L-Glutamic acid & + & $21 \cdot 2$ & . & $0 \cdot 6$ & $19 \cdot 5$ \\
\hline & - & $6 \cdot 8$ & $24 \cdot 6$ & $3 \cdot 7$ & $24 \cdot 3$ \\
\hline L-Alanine & + & 0 & . & $5 \cdot 4$ & $11 \cdot 1$ \\
\hline & - & 0 & $10 \cdot 8$ & $18 \cdot 1$ & $26 \cdot 8$ \\
\hline Glycine & + & $\mathbf{0}$ & . & $3 \cdot 5$ & $4 \cdot 8$ \\
\hline & - & $\mathbf{0}$ & $7 \cdot 9$ & $10 \cdot 2$ & $12 \cdot 9$ \\
\hline \multicolumn{6}{|c|}{ Expt. B } \\
\hline None & + & $0 \cdot 3$ & . & $0 \cdot \overline{5}$ & . \\
\hline & - & 0 & $5 \cdot 2$ & $1 \cdot 6$ & $\cdot$ \\
\hline L-Glutamic acid & + & $10 \cdot 8$ & $\cdot$ & $0 \cdot 9$ & $8 \cdot 0$ \\
\hline & - & $\mathbf{3} \cdot \mathbf{0}$ & $10 \cdot 4$ & $6 \cdot 5$ & $16 \cdot 8$ \\
\hline \multirow[t]{2}{*}{ L-Aspartic acid } & + & 0 & . & $10 \cdot 8$ & $15 \cdot 0$ \\
\hline & - & 0 & 34.8 & $14 \cdot 9$ & $21 \cdot 2$ \\
\hline
\end{tabular}

Under parallel conditions in the dark no disappearance of $\mathrm{L}$-glutamic acid from the medium was observed nor was the small endogenous carbon dioxide production increased by the presence of substrate.

Distribution of other products of L-glutamic acid dissimilation. In these experiments the contents of each manometer vessel were centrifuged, washed twice and finally resuspended in $0.85 \% \mathrm{NaCl}$. For the estimation of free glutamic acid in the organism, the bacteria were disrupted by boiling as described by Gale (1947). For the estimation of total L-glutamic acid (combined plus free), the bacteria were hydrolysed in $6 \mathrm{~N}-\mathrm{HCl}$ in a sealed tube for $16 \mathrm{hr}$. at $105^{\circ}$ and the hydrochloric acid removed by vacuum distillation. Cellular ammonia and amide nitrogen were estimated by hydrolysing the cells in $\mathrm{N}-\mathrm{H}_{2} \mathrm{SO}_{4}$ at $100^{\circ}$ for $3 \mathrm{hr}$. according to the method of Pucher, Vickery \& Leavenworth (1935), and determining the ammonia as described above.

Although Rhodospirillum rubrum takes up L-glutamic acid readily, no significant quantity has ever been found adsorbed on the outside of, or free inside, 
the cell. Of the glutamic acid-nitrogen disappearing from the medium, 10$20 \%$ could be accounted for as bound glutamic acid in the cell, while the increase in ammonia and amide groups accounted for an additional $25 \%$ (Table 3). The remaining 55-65\% was not present as L-glutamic acid and probably had been metabolized further.

Table 3. Distribution of some intracellular products of L-glutamic acid dissimilation by light-grown organisms

Experiments carried out in Warburg flasks under argon in light at $30^{\circ}$. Each flask contained $35.7 \mathrm{mg}$. dry wt. bacteria suspended in $0.067 \mathrm{~m}$-phosphate buffer $\mathrm{pH} 7 \cdot 0$. Duration of experiment $3 \mathrm{hr}$.; $50 \mu$ mole L-glutamic acid added initially. Results expressed per $100 \mathrm{mg}$. dry wt. bacteria.

\begin{tabular}{|c|c|c|}
\hline & \multicolumn{2}{|c|}{ Additions } \\
\hline & $\begin{array}{c}\text { Nil } \\
(\mu \text { mole })\end{array}$ & $\begin{array}{c}\text { L-glutamic acid } \\
(\mu \text { mole })\end{array}$ \\
\hline L-Glutamic acid metabolized & & $52 \cdot 3$ \\
\hline $\mathrm{NH}_{3}$ formed & $0 \cdot 8$ & $2 \cdot 4$ \\
\hline Change in cellular L-glutamic acid & $-4 \cdot 5$ & $+5 \cdot 0$ \\
\hline Change in cellular 'ammonia' & $-3 \cdot 4$ & $+11 \cdot 3$ \\
\hline
\end{tabular}

Initial level of cellular L-glutamic acid : $43 \cdot 7 \mu$ mole.

Initial level of cellular 'ammonia': $59 \cdot 3 \mu$ mole.

The effect of incubation in carbon dioxide, nitrogen and hydrogen. The disappearance of glutamic acido ver a $3 \mathrm{hr}$. period was the same under $5 \% \mathrm{CO}_{2}+$ $95 \%$ argon as under $100 \%$ argon but the presence of a $\mathbf{K O H}$ paper decreased the rate. Further information on the role of carbon dioxide in glutamic acid metabolism was obtained from experiments performed in Krebs's vessels with nitrogen in the gas phase. Three Krebs's vessels were initially placed in the dark at $0^{\circ}$ to decrease the metabolism. The vessels were then evacuated and filled, one with $5 \% \mathrm{CO}_{2}-95 \% \mathrm{~N}_{2}$ and the other two with $\mathrm{CO}_{2}$-free nitrogen. One of these was then closed, and the other gassed with $\mathrm{CO}_{2}$-free nitrogen throughout the experiment. The disappearance of glutamic acid was greatest in an atmosphere enriched with $\mathrm{CO}_{2}$, suggesting that it was probably essential for glutamic acid uptake (Table 4).

Table 4. Effect of carbon dioxide on L-glutamic acid disappearance in the presence of light-grown organisms

Experiments carried out in Krebs's vessels in light at $30^{\circ}$. Vessel contained $47 \cdot 1 \mathrm{mg}$. dry wt. bacteria suspended in $4.0 \mathrm{ml}$. $0.067 \mathrm{~m}$-phosphate buffer $\mathrm{pH} 7.0$. Duration of experiment $3 \mathrm{hr}$.; $50 \mu$ mole L-glutamic acid added initially.

Vessel gassed with $95 \% \mathrm{~N}_{2}+5 \% \mathrm{CO}_{2}$ L-glutamic acid disappearance ( $\mu$ mole)

Vessel gassed initially with $\mathrm{CO}_{2}$-free $\mathrm{N}_{2}$ $42 \cdot 9$ and then closed

Vessel gassec, with $\mathrm{CO}_{2}$-free $\mathbf{N}_{2}$ initially $17 \cdot 4$ and throughout the experiment 
Replacement of argon in the gas phase by hydrogen or nitrogen did not alter the rate of glutamic acid disappearance although nitrogen, but not hydrogen, completely inhibited hydrogen production.

The amino acid metabolism of dark-grown organisms aerobically in the dark

Studies of amino acid metabolism by these organisms, under aerobic conditions in the dark, was made difficult by the high rate of endogenous metabolism. The rate of oxygen uptake with glutamic acid, the most actively attacked of the four amino acids tested, was never greater than twice the endogenous value. Previous aeration of a washed suspension of the organism decreased the endogenous respiration by $50 \%$ but did not increase the proportion by which the oxygen uptake was raised on the addition of glutamic acid. All the experiments were therefore carried out with organisms harvested and washed by the usual procedures.

The effect of substrate metabolism on the endogenous respiration. The organisms incorporated ${ }^{14} \mathrm{C}$ into their endogenous reserves during growth in the normal medium plus $2 \cdot 1 \mu \mathrm{g}$. $/ \mathrm{ml}$. of doubly-labelled acetate. After harvesting, the cells were washed twice and then incubated in Conway units in the presence or absence of an excess of an amino acid. The amount of ${ }^{14} \mathrm{CO}_{2}$ produced gives a measure of the magnitude of the endogenous respiration, assuming that the endogenous substrates have been uniformly labelled under these growth conditions. All the amino acids tested diminished the endogenous metabolism (Table 5). L-Aspartic acid had the greatest effect, decreasing it by $45 \%$, whereas

Table 5. The effect of amino acids on the endogenous metabolism of dark-grown organisms

The organisms were grown on the normal medium plus $2 \cdot 1 \mu \mathrm{g} . / \mathrm{ml}$. of sodium acetate doubly labelled with ${ }^{14} \mathrm{C}$ and having a specific activity of $48 \mu \mathrm{C}$. $/ \mathrm{mg}$. Incubation was in Conway units aerobically in the dark at $30^{\circ}$. Outer compartment contained c. $1.5 \mathrm{mg}$. dry wt. of bacteria suspended in $0.067 \mathrm{M}$-phosphate buffer $\mathrm{pH} 7 \cdot 0$. ${ }^{14} \mathrm{CO}_{2}$ respired was trapped by $\mathrm{Ba}(\mathrm{OH})_{2}$ on a polythene disk, dried down and the ${ }^{14} \mathrm{C}$ estimated. Duration of experiment $3 \mathrm{hr}$; $20 \mu$ mole of amino acid added initially. Radioactivity of bacteria added to each vessel 10,600 counts/min.

$\begin{array}{lcc}\text { Amino acid added } & \begin{array}{c}\text { Relative rate of } \\ \text { of } \mathrm{CO}_{2} \text { formed } \\ \text { (counts/min.) }\end{array} & \begin{array}{c}\text { endogenous respira- } \\ \text { tion based on } \\ \text { radioactivity of } \\ \text { respired } \mathrm{CO}_{2}\end{array} \\ \text { None } & 295 \pm 12 & 100 \\ \text { L-Glutamic acid } & 173 \pm 12 & 59 \\ \text { L-Aspartic acid } & 163 \pm 28 & 55 \\ \text { L-Alanine } & 270 \pm 6 & 91 \\ \text { Glycine } & 251 \pm 16 & 85\end{array}$

L-alanine decreased it by only $9 \%$. On the basis of these results, the carbon dioxide output and oxygen uptake values quoted in Table 6 have been corrected for the decreased endogenous metabolism in the presence of each amino acid. When these corrections were made the R.Q. values observed in the presence of the amino acids approached more closely the theoretical values for complete oxidation than did the uncorrected figures (Table 6). The results suggest that the amino acids were oxidized to completion. 
Table 6. Metabolism of L-glutamic acid, L-aspartic acid, L-alanine and glycine by dark-grown organisms

Experiments carried out in Warburg flasks aerobically in the dark at $30^{\circ}$. Main compartment contained $13 \cdot 1 \mathrm{mg}$. (Expt. A) and $18.5 \mathrm{mg}$. (Expt. B) dry wt. of bacteria suspended in $0.067 \mathrm{~m}$-phosphate buffer pH 7.0. Duration of Expt. A $8 \frac{1}{2} \mathrm{hr}$., B $5 \mathrm{hr}$.; $10 \mu$ mole of amino acid added initially. The corrected $\mathrm{CO}_{2}$ output has been calculated by subtraction of the decreased endogenous $\mathrm{CO}_{2}$ output in the presence of each amino acid (Table 5). A proportional decrease in oxygen uptake has been assumed.

\begin{tabular}{|c|c|c|c|c|c|c|c|c|c|c|}
\hline \multirow{4}{*}{$\begin{array}{l}\text { Expt. } \\
\text { A }\end{array}$} & \multirow[b]{2}{*}{$\begin{array}{l}\text { Amino acid } \\
\text { added }\end{array}$} & \multirow{2}{*}{$\begin{array}{c}\text { Amount } \\
\text { metabolized } \\
(\mu \text { mole })\end{array}$} & \multirow{2}{*}{$\underset{(\mu \mathrm{mole})}{\mathrm{NH}_{3}}$} & \multicolumn{2}{|c|}{$\begin{array}{c}\mathrm{CO}_{2} \\
(\mu \mathrm{mole})\end{array}$} & \multicolumn{2}{|c|}{$\overbrace{}^{\begin{array}{c}\mathrm{O}_{2} \\
(\mu \mathrm{mole})\end{array}}$} & \multicolumn{3}{|c|}{$\underbrace{\text { R.Q. }}$} \\
\hline & & & & o.v.* & $\overbrace{\text { c.v. }}$ & o.v. & $\overrightarrow{\text { c.v. }}$ & o.v. & c.v. & T.v. \\
\hline & None & 0 & $2 \cdot 6$ & $27 \cdot 6$ & $\cdot$ & $31 \cdot 1$ & $\dot{x}$ & $0 \cdot 89$ & $\cdot$ & $\cdot$ \\
\hline & Glycine & $5 \cdot 5$ & $7 \cdot 7$ & $45 \cdot 2$ & $21 \cdot 7$ & $44 \cdot 3$ & $17 \cdot 9$ & $1 \cdot 02$ & $1 \cdot 21$ & $1 \cdot 33$ \\
\hline & L-Aspartic acid & $10 \cdot 0$ & $10 \cdot 5$ & $58 \cdot 2$ & $43 \cdot 0$ & $51 \cdot 2$ & $34 \cdot 1$ & $1 \cdot 14$ & $1 \cdot 26$ & $1 \cdot 33$ \\
\hline & L-Alanine & $9 \cdot 0$ & $8 \cdot 4$ & $43 \cdot 1$ & $18 \cdot 0$ & $46 \cdot 8$ & $18 \cdot 6$ & $0 \cdot 94$ & 0.97 & $1 \cdot 00$ \\
\hline $\mathbf{B}$ & None & 0 & $1 \cdot 6$ & $47 \cdot 3$ & $\cdot$ & $50 \cdot 7$ & $\therefore$ & $0 \cdot 93$ & $\therefore$ & : \\
\hline & L-Glutamic acid & $9 \cdot 0$ & $10 \cdot 0$ & $75 \cdot 2$ & $47 \cdot 3$ & $74 \cdot 2$ & $44 \cdot 2$ & $1 \cdot 01$ & 1.07 & $1 \cdot 11$ \\
\hline
\end{tabular}

\section{DISCUSSION}

The carbon:nitrogen ratio of many micro-organisms is approximately $5: 1$ (Buchanan \& Fulmer, 1928). The results suggest that the light-grown organisms form more ammonia per mole of substrate attacked from amino acids with $\mathrm{C}: \mathrm{N}$ ratios less than $5: 1$ than they do from amino acids with a ratio similar to that of the organisms. For instance, only $15-30 \%$ of the theoretical amount of ammonia was formed from glutamic acid $(\mathrm{C}: \mathrm{N}$ ratio of $5: 1)$, whereas $80 \%$ of the theoretical amount was released during the metabolism of glycine (C:N ratio of $2: 1$ ). Similarly, the amount of carbon dioxide produced seems to be related to the state of oxidation of the amino acid. Thus with aspartic acid, which contains $48 \%$ oxygen, more carbon dioxide was produced per mole of substrate disappearing than with alanine which contains only $36 \%$. There is a marked similarity between these results and those quoted by van Niel (1941) for the assimilation of carbon dioxide during the metabolism of fatty acids by this organism. He found that as the percentage of oxygen in the molecule decreased, the amount of carbon dioxide assimilated per molecule of substrate metabolized increased.

Further investigations with ${ }^{14} \mathrm{C}$ labelled amino acids are being carried out to determine into what cellular components the amino acid carbon is incorporated.

In Table 6 a comparison has been made between the R.Q. values for complete oxidation of glycine, alanine, aspartic acid and glutamic acid and the corrected observed R.Q. values of dark-grown organisms. In arriving at these observed R.Q. values two assumptions have been made: $(a)$ that the R.Q. value for the endogenous metabolism does not change in the presence of the substrate so that a decrease of endogenous carbon dioxide production in the presence of an amino acid is accompanied by a proportional reduction in oxygen uptake; $(b)$ that the decrease in endogenous metabolism remains constant 
throughout the experiment. There is no evidence to support or disprove the validity of these assumptions, but if they are true it would appear that alanine, aspartic acid, glutamic acid and possibly glycine are oxidized almost to completion in the dark by dark-grown Rhodospirillum rubrum.

The author wishes to express his thanks to the Medical Research Council for a Scholarship for Training in Research Methods, and to Dr K. McQuillen for much helpful advice and encouragement.

\section{REFERENCES}

Buchanan, R. E. \& Fulmer, E. I. (1928). Physiology and Biochemistry of Bacteria. London: Baillière, Tindall and Cox.

Chibnall, A. C., Rees, M. W. \& Williams, E. F. (1943). The total nitrogen content of egg albumin and other proteins. Biochem. J. 37, 354.

Cocking, E. C. \& Yemm, E. W. (1954). Estimation of amino acids by ninhydrin. Biochem. J. 58, xii.

Conway, E. J. (1950). Microdiffusion Analysis and Volumetric Error. London: Crosby Lockwood and Son Ltd.

Gale, E. F. (1945). Studies on bacterial amino acid decarboxylases. 5. The use of a specific decarboxylase preparation in the estimation of amino acids and in protein analysis. Biochem. $J .39,46$.

Gale, E. F. (1947). Assimilation of amino acids by bacteria. 1. The passage of certain amino acids across the cell wall and their concentration in the internal environment of Streptococcus faecalis. J. gen. Microbiol. 1, 53.

Gest, H., Kamen, M. D. \& Bregoff, H. M. (1950). Photoproduction of hydrogen and nitrogen fixation by Rhodospirillum rubrum. J. biol. Chem. 182, 153.

Kohlmiller, E. F. \& Gest, H. (1951). A comparative study of the light and dark fermentations of organic acids by Rhodospirillum rubrum. J. Bact. 61, 269.

MaRкhaм, R. (1942). A steam distillation apparatus suitable for micro-Kjeldahl analysis. Biochem. J. 36, 790.

NiEl, C. B. VAN (1941). The bacterial photosyntheses and their importance for general problems of photosynthesis. Advanc. Enzymol. 1, 263.

Parnas, J. K. \& Heller, J. (1924). Über den Ammoniakgehalt und über die Ammoniakbildung im Blute. Biochem. Z. 152, 1.

Pucher, G. W., Vickery, H. B. \& Leavenworth, C. S. (1935). Determination of ammonia and amide nitrogen in plant tissues. Industr. Engng Chem. (Anal.), 7, 152.

Umbreit, W. W., Burris, R. H. \& Stauffer, J. F. (1949). Manometric Techniques and Tissue Metaholism. Minneapolis: Burgess Publishing Co.

(Received 2 November 1955) 